\title{
Evidence-based social work på svenska - att sammanställa systematiska kunskapsöversikter
}

\author{
MARGARETA HYDÉN
}

\begin{abstract}
Den systematiska kunskapsöversikten intar en central roll inom det evidensbaserade arbetet. För att kunna vara relevanta för praktiken kan dessa översikter inte låta sig nöja med att besvara frågor om vilka metoder som är verksamma - de måste även kunna besvara frågor om var, när och hur de är verksamma, samt vilken mening socialarbetare och brukare tillskriver dem.
\end{abstract}

Den systematiska kunskapsöversikten intar en central roll inom det evidensbaserade sociala arbetet. Den består av en sammanvägning av resultaten från ett stort antal studier av god kvalitet. Syftet är att kunna visa på nyttan eller effekterna av olika insatser, åtgärder eller behandlingsmetoder genom att besvara frågor som: Vad fungerar? Vad fungerar inte? Vad vet vi för lite om? Tanken är att det successivt skall sammanställas kunskapsöversikter över

Margareta Hydén, professor i socialt arbete vid Institutionen för Tema Barn, Linköpings universitet verkningsfulla metoder för område efter område i socialt arbete. Socialstyrelsen skall kunna basera sina rekommendationer på dem och de skall kunna vara vägledande för prioriteringar inom enskilda kommuner. Översikterna skall också kunna användas av enskilda socialarbetare som söker stöd för val av insatser för den enskilde klienten. Det långsiktiga syftet med projektet Evidensbaserat socialt arbete (ESA) är att det inte skall tillämpas några andra metoder $\mathrm{i}$ socialt arbete än de som visat sig vara verkningsfulla i en vetenskaplig prövning. Systematiska kunskapsöversikter är även cen- 
trala dokument när det gäller att definiera evidensbegreppet. Det finns således anledning att närmare studera de metoder som används för att sammanställa kunskapsöversikterna och den kvalitet de håller.

Projektet har kritiserats i Sverige och övriga Norden för att hysa en alltför stor tilltro till att det sociala arbetets praktik är möjligt att reducera till ett mätbart handlande som låter sig utvärderas i form av randomiserade kontrollerade studier (Månsson 2003, Marthinsen 2004, Bergmark \& Lundström 2006, 2007). Vid finska Forsknings- och utvecklingscentralen för social- och hälsovården (STAKES) har man valt en annan väg för att klarlägga vad det är som fungerar och inte fungerar i det sociala arbetet. STAKES är ett sektorsforskningsinstitut som är underställt social- och hälsovårdsministeriet, med speciellt uppdrag att följa upp och utvärdera verksamheter inom social- och hälsovården (www.stakes.fi). Centrala forskningsområden är klientarbetets processer, samt beskrivning och spridning av "god praktik». Enligt STAKES definition har "god praktik" en processartad karaktär och utgör ett etiskt godtagbartsätt att verka med sikte på att åstadkomma goda resultat. STAKES arbetar med ett brett upplagt praktiknära forskningsprogram och vinnlägger sig om att inkludera brukarnas synpunkter (www.sisiaaliporti.fi/godpraktik). Forskningsprogrammet bygger på ett teoretiskt perspektiv som har stora likheter med det som Donald Schön (1991) och efterföljare formulerade som reflexiv praktik. IEngland syftar verksamheten vid Social Care Institute for Excellence (SCIE) till att utveckla en kunskapsbas och utforma riktlinjer för en "best practice» inom socialt arbete och social omsorg, liktydig med "evidence-based practice». Även i den engelska diskussionen har kritik framförts mot ett alltför ensidigt gynnande av experimentell metodik när det gäller att fastslå vad som är "best practice». Kritikerna har också varnat för tendensen att utveckla en naiv tilltro till att det går att implementera metoder utan att fokusera relationen mellan socialarbetare och brukare eller utan att inkludera ett reflexivt förhållningssätt (se exempelvis Webb 2001 och Ferguson 2003). Det engelska ESA projektet har kraftfullt försvarats av dess företrädare (se exempelvis Sheldon 2001).

Diskussionen har inte gällt $o m$ det sociala arbetets praktik skall vara grundat på empiriska studier, vilket samtliga debattörer förefaller vara överens om, utan hur de skall vara utformade och vilka kunskapsteoretiska antaganden de skall vila på. Med den här artikeln vill jag lämna ett bidrag till diskussionen. I artikeln undersöker jag vad "evidensbasering" betyder, såsom det kommer till uttryck genom de metoder som hittills utvecklats för att genomföra systematiska kunskapsöversikter över sociala metoder.

Artikeln består av fyra delar. Den börjar med en orientering om projektet "evidensbaserat socialt arbeter. Sedan övergår jag till att göra en kritisk granskning av den i Sverige vanligast förekommande modellen för att sammanställa systematiska kunskapsöversikter, den jag kallar RCT- modellen, därför att den gynnar "randomized controlled trials", randomiserade kontrollerade studier och metaanalyser i översiktsarbetet. Modellen skulle också kunna kallas Campbell Collaboration-modellen, efter den orga- 
nisation som utvecklat den. Jag kommer att fördjupa diskussionen genom en analys av två svenska exempel. I artikeln kommer jag att visa att det finns anledning att ifrågasätta om RCT-modellen verkligen tjänar sitt syfte, inte minst därför att den leder till att en stor mängd potentiellt relevant material exkluderas. Jag kommer också att visa att detta leder till validitets- och reliabilitetsproblem som är så omfattande att det finns anledning att ifrågasätta om de kunskapsöversikter i socialt arbete som framställs enligt RCT-modellen verkligen uppfyller grundläggande vetenskapliga krav.

I den tredje delen för jag in de tankesätt som utvecklats runt det jag kallar Kartmodellen. Modellen skulle också kunna kallas EPPI-centre modellen, efter Evidence for Policy and Practice Information and Coordinating Centre in the Social Science Research Unit vid University of London, där den först började utvecklas, eller SCIE-modellen efter Social Care Institute for Excellence i London, där den också tillämpas. Modellen utgör ett försök att vidga kriterierna för vilka studier som skall ingå i kunskapsöversikterna. Avslutningsvis kommer jag att föra en diskussion om hur jag ser på frågan om den fortsatta utvecklingen av ett evidensbaserat socialt arbete i Sverige.

\section{Evidens-based practice - en bakgrund}

"The evidence movement» har den kallats, den internationella "rörelse» som sedan slutet av 1990- talet arbetat för att implementera en evidensbaserad praktik i socialt arbete (Oakely et al. 2005). Den har tagit den evidensbaserade medicinen (EBM) som $\sin$ förebild. Den allmänt vedertagna definitionen av EBM formulerades ursprungligen av Dr David Sackett och hans kollegor vid McMasters University i Ontario, Kanada:

"Evidence-based medicine is the conscientious, explicit and judicious use of current best evidence in making decisions about the care of individual patients" (Sackett et al. 1996)

När det gäller definitionen av Evidencebased practice är de vanligast förekommande definitionerna snarlika, som detta exempel:

"Evidence- based practice or EBP can be defined very simple as 'treatment [or intervention] based on the best available science or research evidence' " (McNeece \& Thyer 2004 p. 8).

Den evidenbaserade rörelsen inom socialt arbete har potential att iscensätta ett paradigmskifte. Ett grundläggande drag i detta nya paradigm är att lyfta fram handlingsdimensionen i socialt arbete och framför allt de sociala insatsernas effekt. Genom att sätta handlingsdimensionen i fokus gör den evidensbaserade rörelsen även en omvärdering av vad som är ämnesspecifik forskning i socialt arbete. I tidskrifter som Research on Social Work Practice, Journal of Social Work Education och Evidence \& Policy, argumenterar förespråkare för det evidensbaserade sociala arbetet för att forskning som rör metodutveckling och insatsers utfall, skall värderas högre än forskning som undersöker sociala fenomen eller syftar till teoriut- 
veckling (Gibbs \& Gambrill 2002, Gilgun 2005, Thyer 2001, Regehr et al. 2007). En social praktik baserad på sedvänjor och värderingar avvisas kraftfullt (Gambrill 1999), liksom beskrivningar av socialt arbete som "konst" och socialarbetaren som "konstnär" (se exempelvis England 1986). Välkomnas gör den forskning som ser som sin huvuduppgift att med vetenskaplig metodik belägga utfall och effektstorlek av insatser i socialt arbete.

Den evidensbaserade rörelsen har beskrivits som ett utpräglat "top down" projekt som vuxit fram ur politikers och andra beslutfattares behov av att modernisera välfärdsstaten och av att skaffa bättre underlag för beslut om vilka insatser som kan rekommenderas (Konnerup 2005). Det är således inte frågan om någon "gräsrotsrörelse« som artikulerar socialarbetares- eller klienters önskan att utveckla arbetet. Dess syfte är grundat i en stark tilltro till socialarbetares vilja och förmåga att handla rationellt och strukturerat, med siktet inställt på att skapa förändring: "Ideology is out and pragmatism is in: What matters is what works", sammanfattade Merete Konnerup (2005), avdelningschef vid det Nordiska Campbell Centret i Köpenhamn, under en föreläsning.

Konnerup menar att det finns minst fyra skäl till varför den evidensbaserade rörelsen tagit fart just nu. Det första skälet är, att i takt med informationssamhällets expansion blir experter alltmer ifrågasatta av människor som efterfrågar deras tjänster. Det andra skälet hänger samman med det första: Allmänheten har blivit alltmer kritisk och krävande som konsument av välfärdstjänster. Det tredje är, att forskare som är finansierade med skattemedel ställs inför ökade krav att producera användbara resultat. Det fjärde skälet gäller specifikt för de nordiska länderna, nämligen det faktum att den nordiska välfärdsstatsmodellen under de senaste 40 åren växt i kostnad och omfattning på ett sätt som är ohållbart i längden. För att möta dessa krav tvingas politiker och beslutsfattare att finna alternativa finansieringskällor, men framför allt tvingas de till prioriteringar och till att försöka fastställa vad som är rimliga krav att ställa på välfärdstjänsters utformning och innehåll. Politiker och andra beslutsfattare behöver helt enkelt underlag för att prioritera, och de söker vetenskapligt producerad kunskap för att underbygga sina beslut (Konnerup 2005). Denna kunskap är dock svårtillgänglig, inte minst genom sin mängd och mångfald. Den engelska pedagogen Ann Oakely, menar att den stora mängd kunskap som produceras inom den "globala kunskapsekonomin» kräver internationella nätverk för att kvalitetsgranska och sammanställa vetenskapligt hållbar kunskap i en hanterbar form (Oakely et al. 2005).

I syfte att producera systematiska kunskapssammanställningar har statligt finansierade verksamheter tillskapats i flera länder. Så har exempelvis skett i Storbritannien, där utvecklingen av en evidensbaserad social praktik fördes upp på New Labours agenda när de erövrade regeringsmakten år 1997. Med Cochrane Collaboration som utvecklats inom EBM som förebild, startade år 2000 Campbell Collaboration, ett internationellt nätverk för beslutsfattare, forskare och praktiker med intresse för att utveckla systematiska kunskapsöversikter över sociala insatser. Nätverkets styrgupp 
består av 16 medlemmar, varav tio är från USA (www.campbellcollaboration.org). I Sverige etablerades Institutet för utveckling av metoder $i$ socialt arbete (IMS) vid Socialstyrelsen i oktober 2004. IMS uppgift är att bidra till utvecklingen av en bättre praktik i socialt arbete genom att förse det sociala området med kunskapsöversikter över vilka insatser och metoder som fungerar. Institutet genomför även egna utvärderingar av sociala insatser, samt utvecklar systematiska bedömningsmetoder. IMS föregångare CUS spelade en viktig roll i tillskapandet av Campbell Collaborations nordiska del, lokaliserat till Köpenhamn (www.socialstyrelsen.se/IMS).

\section{RCT-modellen}

Genom att initiera arbetet med att framställa systematiska kunskapsöversikter, tog Campbell Collaboration initiativ till att "göra den internationella forskningens samlade erfarenheter om verkningsfulla insatser och program mer lättillgängliga för praktiker och beslutsfattare" (www.socialstyrelsen.se/IMS/Campbell_Collaboration). Genom att även "ta ansvar för kvalitetsgranskning av forskningen" gör nätverket anspråk på att få fastställa de kriterier som skall gälla för att fastställa kvaliteten hos de studier som skall få ingå i kunskapsöversikterna. Målet är att skapa en databas, Campbell Library, för att samla de systematiska kunskapsöversikter som godkänts av Campbell Collaboration Review Group och Campbell Collaboration Steering Committee. Ambitionen är att Campbell Library skall bli normgivande för en evidensbase- rad social praktik över hela världen (www. campbellcollaboration.org).

Enligt de kvalitetskriterier som utformats av Campbell Collaboration, tillskrivs inte alla slag av forskningsmetoder och undersökningsdesign lika värde när det gäller att fastställa graden av evidens för enskilda studier. Campbell Collaboration Steering Committee har fastställt följande hierarki när det gäller bedömning av evidensgrad:

"(1) Strong evidence from at least one systematic review of multiple well-designed randomized controlled trials (RCTs)

(2) Strong evidence from at least one properly designed RCT of appropriate size

(3) Evidence from well-designed non-experimental studies from more than one centre or research group

(4) Opinions of respected authorities, based on clinical evidence, descriptive studies or reports of expert committee" www.campbellcollaboration.org.

Det är detta gynnande av randomiserade kontrollerade studier i de systematiska kunskapsöversikterna som gjort att jag benämnt Campbell Collaborations modell „RCT-modellen". Vad är då en randomiserad kontrollerad studie och vad för slags kunskap kan den generera?

Hörnstenarna i en randomiserad kontrollerad studie är manipulation (de individer som ingår $i$ behandlingsgruppen får någon form av behandling, individerna i kontrollgruppen får "det vanliga» eller ingen behandling alls), kontroll (behandlingsgrupp och kontrollgrupp måste vara så lika som möjligt, det enda som skall skilja

Margareta Hydén: Evidence-based social work på svenska... 
är att den ena får behandling), samt randomisering (utgör medlet för att garantera att grupperna är lika, man låter slumpen avgöra vilka individer som skall tillhöra behandlings- respektive kontrollgrupp). Det är också viktigt att det inte sker en sammanblandning (confounding) av faktorer som okontrollerat kan påverka resultatet.

Den fråga en randomiserad kontrollerad studie kan besvara är: "Vilken effekt har en viss insats för en försöksgrupp i jämförelse med en kontrollgrupp«. Exempel på frågor som man inte kan besvara är: "Skulle en annan insats ha haft samma eller bättre effekt, varför har insatsen haft/inte haft effekt, har den haft effekt på vissa i försöksgruppen men inte på andrau. En randomiserad kontrollerad studie ger heller inte någon kunskap om möjligheten att nå samma resultat om en social metod förs över från ett socialt- och kulturellt sammanhang till ett annat.

Enligt RCT-modellen består arbetet med att framställa systematiska kunskapsöversikter i huvudsak av att ur tillgängliga databaser identifiera randomiserade kontrollerade studier av god vetenskaplig kvalitet för inklusion i översikten. Arbetet börjar med att inklusionskriterierna fastställs. De skall relatera till population, intervention, studiedesign, studiekvalitet och utfallsmått. Nästa steg är att lägga upp en sökstrategi, det vill säga välja sökord och kombinationer av sökord samt välja relevanta databaser. Databassökningen kan eventuellt kompletteras men whandsökning" av tidskrifter och med kontakt med forskare inom området - allt för att säkerställa att samtliga studier identifieras. När sökarbetet är avslutat granskar två personer de titlar och abstrakt som identifierats och avgör om de motsvarar inklusionskriterierna eller inte. De artiklar som inkluderas i denna första analysomgång beställes och läses i fulltext och studierna evidensgraderas, varefter det slutliga beslutet om inklusion eller exklusion tas. I praktiken är det framför allt studier med evidensgrad ett och två enligt Campbell Collaborations kriterier som inkluderas.

När RCT-modellen tillämpas ges prioritet för utfallstudier som beräknar effektstorlek, d.v.s. studier som mäter den genomslagskraft som en insats har haft. Sedan säkerställs effektstorleken för insatsen i fråga genom att resultaten från flera utfallsstudier läggs samman. Metoden för att göra denna sammanvägning är metaanalysen, en teknik där data från flera utfallsstudier av samma intervention extraheras och återanvänds för att göra en ny analys, baserad på den större datamängden. Genom en statistisk sammanslagning av resultaten redovisar metaanalysen ett samlat resultatmått. Den ger därigenom en sammanfattande uppfattning om huruvida en metod är bättre än de metoder de jämförts med, vilket ofta är olika slag av "vanliga» behandlingar eller att stå på väntelista.

\section{Brist på RCT-design i socialt arbete}

Även om det produceras en stor mängd kunskap inom den del av den nglobala kunskapsekonomin" som är av relevans för socialt arbete, så existerar få studier som uppfyller RCT-modellens krav. Ann 
Oakley och hennes medarbetare vid EPPIcentre liknar arbetsprocessen vid att »söka efter en nål i en höstack" (Oakely et al. 2005).

Det finns flera skäl till varför så få metoder i socialt arbete är utvärderade som randomiserade kontrollerade studier. De har samtliga att göra med det sociala arbetets karaktär. För att en RCT-studie skall kunna genomföras på ett tillförlitligt sätt, krävs tydligt avgränsade, dokumenterade och omsorgsfullt implementerade insatser. Det måste vara möjligt att lita på att socialarbetaren utövar metoden på föreskrivet sätt. Ett kännetecken för samtliga interventioner inom socialt arbete, vare sig de är manualbaserade eller inte, är att de nödvändigtvis måste tillämpas under givna ramar, såväl när det gäller organisationsform som juridiska regler. Det innebär att en viss behandlingsform som exempelvis gäller unga med beteendeproblem, kommer att tillämpas olika inom BUP, den särskilda ungdomsvården och socialtjänstens ungdomsgrupp. För att möta dessa och liknade förhållanden innehåller många manualer en viss möjlighet till anpassning. Det finns dock gränser för vilka avvikelser som kan tillåtas för att en metodutvärdering skall kunna genomföras med en sådan exakthet att rimliga krav på validitet och reliabilitet upprätthålls. Socialarbetarens professionella skicklighet - eller eventuella brist på skicklighet - har också betydelse för hur han eller hon kommer att tillämpa manualen.

Ytterligare ett skäl till varför det råder brist på randomiserade kontrollerade studier i socialt arbete är att de inte ger tillräckligt relevant kunskap. För att kunna vara användbar i det sociala arbetets prak- tik räcker det inte att en utvärdering visat att metoden varit verksam - i medeltal för en försöksgrupp i jämförelse med en kontrollgrupp. Socialarbetaren måste också veta något om på vilket sätt den fungerar, för vem eller vilka, om vissa individer eller grupper av individer inom försöksgruppen haft nytta av metoden och andra inte, hur den upplevs, samt om den kan leda till oförutsedda och oavsiktliga konsekvenser. En randomiserad kontrollerad studie ger helt enkelt inte tillräckligt relevant kunskap för att tillfredställa det sociala arbetets praktik. Detta leder till att socialt arbete ofta utvärderas med andra metoder, som föreoch eftermätningar, processbeskrivningar och intervjuer med brukare.

\section{RCT-modellen i svensk praktik}

I Sverige är det IMS som arbetar med att utveckla systematiska kunskapsöversikter. IMS har anslutit sig till RCT-modellen och är också med och driver det Nordiska Campbell Centret i Köpenhamn. Knut Sundell, IMS chef, har formulerat följande definition av begreppet nevidensbaserad kunskap»:

"Evidensbaserad: Kunskap som bygger på kontrollerade undersökningar, framför allt när flera av varandra oberoende forskare kommer fram till samma slutsatser om en viss bestämd intervention" (Sundell et al. 2006 s.78)

Hittills har IMS slutfört arbetet med två kunskapsöversikter, som bägge illustrerar problemen med RCT-modellen. 


\section{Systematisk kunskapsöversikt I}

Den första översikten är "Effekter av psykosociala insatser för personer med schizofreni eller bipolär sjukdom. En sammanställning av systematiska översikter» (Öjehagen et al. 2006). Översikten gjordes på uppdrag av handikappenheten vid Socialstyrelsen, i syfte att få underlag för att formulera riktlinjer för kommunernas arbete med att genomföra Psykiatrireformen 1995. Översikten baseras således inte på primärstudier utan på tidigare genomförda kunskapsöversikter. De inkluderade kunskapsöversikterna gäller personer med schizofreni eller schizofreniliknade tillstånd och för dem inom denna grupp som har ett samtidigt beroende/missbruk av alkohol och/eller narkotika, men även personer med bipolär sjukdom (manodepressiv sjukdom) och för dem inom denna grupp som har ett samtidigt beroende/missbruk av alkohol och/eller narkotika. Slutligen inkluderades systematiska kunskapsöversikter som sammanställt utfallsstudier som gällde personer som riskerar att insjukna i psykos eller som nyligen insjuknat i psykos. De översikter som inkluderades hade i sin tur inkluderat studier av arbetsinriktad rehabilitering, case management, familjeintervention, psykoedukativa insatser, social färdighetsträning, kognitiv träning, psykoterapi, interventioner som syftar till att öka följsamheten till ordinerad behandling, tidiga insatser vid psykos, samt boendestöd. De översikter som inkluderades hade inkluderat studier av fem olika utfall; återfall i sjukdom, vårdbehov (oftast slutenvård), symtomnivå, global funktionsnivå, samt livskvalitet. Studier med RCT-design vägde tyngst i de översikter som denna översikt över översikter inkluderade.

För att finna översikterna genomsöktes tio elektroniska databaser. Utöver detta tillfrågades experter med kunskap om relevanta översikter av studier och på deras rekommendation inkluderades ytterligare översikter. Samtliga abstrakts granskades av två personer. För gruppen "personer med schizofreni och tidigt insjuknande i misstänkt psykossjukdom" påträffades 1291 översikter, varav 24 inkluderades. För gruppen "personer med bipolär sjukdom" påträffades 527 översikter, varav tre inkluderades. För gruppen "personer som ingår i de ovan nämnda grupperna och som samtidigt har ett beroende/missbruk av alkohol och/ eller narkotika" påträffades 950 översikter, varav fyra inkluderades. Huvudsakliga orsaken till exklusion var att översikterna inte innehöll studier av tillräckligt hög kvalitet enligt RCT-modellens krav.

Idealt sett skulle sedan effektstorleken för de olika insatserna ha säkerställts genom att data från de olika utfallsstudierna och kunskapsöversikterna ha återanvänts för en ny analys, en s.k. metaanalys. Så skedde inte. De ingående systematiska kunskapsöversikterna var för heterogena för att effektstorleken skulle kunna vägas samman på detta sätt. I stället genomfördes en analysform som översiktens författare benämner "narrativ« (Öjehagen et al. 2006 s. 29). Detta sätt att använda begreppet »narrativ analys» skall inte sammanblandas med det sätt det vanligtvis används vid narrativa studier inom medicin- och samhällsvetenskap (se exempelvis Hydén \& Hydén 1997). När begreppet används inom ramen för RCT- 
modellen, betyder det en kvantitativ sammanställning av resultaten i en tabell som kompletteras med en beskrivande text.

Resultaten visar att för personer med schizofrenidiagnos är insatsen warbete med stöd» effektivare än "vård som vanligt» för personer med konkurrensutsatt arbete. Det är även effektivare än narbetsförberedande träningsmodeller«. Här kan det dock inte röra sig om jämförbara grupper - en person i ett konkurrensutsatt arbete har rimligtvis en eventuell arbetsträning bakom sig. Insatsen "intensive case management" visade sig leda till färre inläggningar och kortare vårdtid på sjukhus jämfört med ustandardbehandling». "Familjeinterventioner" minskade återfall och minskade inläggningar på sjukhus, samt påverkade det känslomässiga klimatet i familjen på ett positivt sätt, jämfört med "vård som vanligt«. „Psykoedukativa insatser, kognitiv träning, samt insatser för att öka följsamheten" gav samtliga bättre resultat än "vanlig behandling". "Social färdighetsträning" gav bättre resultat i en översikt, men inte i en annan. Den enda behandling som inte gav några entydigt positiva resultat i jämförelse med kontrollgruppen var "psykodynamisk terapi«.

Huvudresultatet var således att alla slag av psykosociala insatser, med undantag för psykodynamisk terapi och för social färdighetsträning i en översikt, var bättre än standardbehandling och vård som vanligt. Ett problem för den socialarbetare som skulle vilja låta sin praktik påverkas av resultatet är att vare sig standardbehandling, vård som vanligt eller någon av de verksamma insatserna beskrivs i översikten. Ytterligare ett problem är att det är svårt att bilda sig en uppfattning om för vem eller vilka insat- serna är verksamma. »Personer med schizofreni och schizofreniliknande tillstånd» och "personer med bipolär sjukdom" behandlas som homogena grupper i kunskapsöversikten. Varje socialarbetare vet att bakom diagnoser som "schizofreni" och "bipolär sjukdom» döljer sig människor av olika ålder, kön, sexuell läggning, etnisk härkomst, sociala förhållanden och familjeliv. "Vad är verksamt för vem» frågar sig socialarbetaren, wunder vilka omständigheter och i vilka sociala sammanhang är metoden verksam och på vilket sätt är den det?»

\section{Systematisk kunskapsöversikt II}

Den andra kunskapsöversikten har jag varit med att genomföra. Den heter: „Utfall och effekter av sociala metoder för kvinnor som utsatts för våld i nära relationer" (Anttila et al. 2006), och har sitt ursprung i ett regeringsuppdrag (Socialdepartementet 2004/9651/ST). Syftet var att kunna stödja en mer enhetlig metodutveckling för socialtjänstens arbete med våldsutsatta kvinnor. De inkluderade studierna gällde kvinnor 15 år och äldre, som blivit utsatta för fysiskt och/eller psykiskt och/eller sexuellt våld i nära relationer. Med "nära relation" menas att den person som utövat våldet är kvinnans partner eller före detta partner. Definitionen av våld inkluderar såväl lindrigare våld som mycket allvarligt. Fyra interventioner inkluderades i översikten: Kvinnojour/ skyddat boende, enskilda samtal/psykoterapi, gruppsamtal/gruppterapi, parsamtal/ parterapi. Två typer av utfall inkluderades: Om våldet upphör eller minskar, samt om

Margareta Hydén: Evidence-based social work på svenska... 
kvinnans välbefinnande och livssituation förbättras. Studier med RCT-design; kvasiexperiment, samt före- och eftermätningar inkluderades. Kvalitetsgraderingen följde de kriterier som utvecklats av U.S. Preventive Services Task Force för att utvärdera program om folkhälsoarbete. De följer Campbell Collaborations rekommendationer.

För att finna samtliga vetenskapliga artiklar som mötte inklusionskriterierna, genomsöktes 16 elektroniska databaser, elva webbplatser och sju tidskrifter för tidsperioden 1985-2005. Ett stort antal artiklar återfanns (5 926). Samtliga abstrakts granskades av två personer. En mindre del av artiklarna (240) bedömdes motsvara inklusionskriterierna och lästes i fulltext. De vanligaste orsakerna till exklusion var att behandlingen inte utvärderats enligt de uppsatta inklusionskriterierna, eller att artikeln huvudsakligen bestod av en beskrivning av behandlingen. Efter denna andra granskning återstod 26 artiklar som rörde 20 olika insatser. Två av insatserna hade utvärderats med metoder som uppfyllde de högsta kvalitetskriterierna. De bedömdes vara av så god vetenskaplig kvalitet att de hade vetenskapligt säkerställda effekter. De gav därför mest utrymme i resultatredovisningen. Övriga 18 insatser redovisades mer summariskt.

Den ena av de två insatser som utvärderats med metoder som uppfyllde de högsta kvalitetskriterierna var ett behandlingsprogram kallat Community-Based Advocacy. Programmet var utvecklat i en industristad i amerikanska mellanvästern. De kvinnor som genomgått programmet hade varit utsatta för grovt våld och levde under socialt utsatta förhållanden. 45 procent var afro-amerikaner, 59 procent var arbetslösa och 76 procent fick någon form av offentligt understöd. Kvinnorna hade bott på kvinnohus innan de deltog i behandlingen. Programmet innebar att kvinnorna blev erbjudna en stödperson under tio veckor efter att de lämnat sitt skyddade boende. Stödpersonerna var kvinnliga universitetsstuderande som genomgått en två terminer lång kurs i samhällspsykologi, följd av en specialkurs om mäns våld mot kvinnor. Kvinnorna träffade sin stödperson fyra till sex timmar per vecka. Exempel på stödinsatser var hjälp till utbildning, arbete och bostad, samt socialt stöd. Kvinnorna i jämförelsegruppen fick "treatment as usual«. Community-Based Advocacy visade sig ha effekt på kvinnornas hälsa och livskvalitet.

Det andra behandlingsprogrammet som var utvärderat med hög kvalitet enligt RCT-modellens krav var Cognitive Trauma Therapy for Battered Women. Programmet var utvecklat på Hawaii för misshandlade kvinnor som lämnat sina män och fått diagnosen posttraumatiskt stressyndrom. För att få ingå i behandlingsprogrammet fick kvinnorna inte missbruka alkohol eller narkotika, eller lida av schizofreni eller bipolär sjukdom. Kontrollgrupp var kvinnor som ställdes på väntelista.

Behandlingen bestod av 90 minuters samtal två gånger per vecka vid åtta till elva tillfällen. Behandlingspersonal var psykologer och sjuksköterskor med specialutbildning i metoden. Den byggde på forskningsresultat om de psykiska symtom i form av posttraumatisk stress som kan drabba kvinnor efter långvarig misshandel. Exempel på teman som togs upp under terapin var skuld 
och skuldkänslor, skyddsplanering, undervisning om »inlärd hjälplöshet» och om vad posttraumatiskt stressyndrom innebär. Programmet visade sig ha effekt på kvinnornas hälsa och livskvalitet.

\section{Validitets- och reliabilitetsproblem inom RCT-modellen}

Eftersom urvalet av artiklar som slutligen inkluderas i översikten inte är representativt för helheten artiklar som återfinns i databaserna, vet inte den presumtive brukaren av kunskapsöversiktens resultat om det finns väl beskrivna och beprövade behandlingsinsatser som inte inkluderats, därför att de utvärderats med en metod som RCT-modellen avvisar. Den enda information som ges är en redovisning av titlarna på de exkluderade studierna. Det kan således vara en mängd studier av relevanta insatser som oredovisat gått förlorade, studier som kan vara genomförda på ett högst tillförlitligt sätt, men med en annan metod än de som RCT-modellen föreskriver och därför förblir okända. Enskilda RCT:s validitet och reliabilitet är prioriterat inom RCT-modellen. När det gäller validitet och reliabilitet för kunskapsöversikten som helhet saknas motsvarande medvetenhet - om man inte räknar det vanligt förekommande resultatet "slutsatserna [i kunskapsöversikten] kan inte generaliseras alltför mycket" som ett utslag av denna medvetenhet (Anttila et al. 2006 s. 8). Den slutsats jag har dragit efter att ha deltagit i arbetet med kunskapsöversikten om insatser för misshandlade kvinnor, är att val av utvär- deringsmetod har att göra med karaktären på behandlingsprogrammet och tillgång till resurser. Tydligt beskrivna och avgränsade insatser är lättare att utvärdera än dess motsats och att genomföra en välgjord randomiserad kontrollerad studie kräver stora resurser i form av tid, pengar och kompetens. I den bästa av världar är det de mest lovande behandlingsprogrammen som får tillgång till dessa resurser - $i$ praktiken kan närheten till en universitetsinstitution med hög utvärderingskompetens vara det avgörande.

Ytterligare ett problem som leder till låg validitet såväl som till låg reliabilitet hos de svenska kunskapsöversikterna hänger samman med att majoriteten av utvärderingarna gäller amerikanska eller brittiska sociala metoder. Det är inte givet att metoder som visat sig verksamma i en annan social- och kulturell kontext är relevanta för det svenska sociala arbetet. Liknande problem gäller de kvinnor behandlingen riktar sig till - ibland lever de under förhållande som är svåra att översätta till svenska förhållanden. Det är heller inte självklart enkelt att tolka resultatet „bättre än behandling som vanligt» ur ett svenskt perspektiv, då »vanligu behandling kan skilja sig avsevärt mellan olika länder.

Om man genom att göra en systematisk kunskapsöversikt vill försöka få svar på om svenska sociala insatser är verksamma, stöter man på motsvarande problem: De låter sig inte utan vidare översättas till amerikanska eller brittiska förhållanden. Ett exempel är en vanlig svensk insats som "vistelse på kvinnohus/kvinnojour». Insatsen är svår att definiera redan på svenska. Svensk kvinnohus/kvinnojours verksam- 
het rymmer allt från ett skyddat boende med anställd personal och verksamhet för barnen, till en kvinnoförening där några få ideellt verksamma kvinnor svarar i telefonen några timmar i veckan (www.roks.se, www.skr.se). De mest näraliggande brittiska verksamheterna är "shelter" eller »battered woman's shelter". Inom amerikansk shelter verksamhet tillämpas "advocacy", ett slags personligt ombud vars exakta motsvarighet inte finns i Sverige.

\section{Kartmodellen}

Mike Fisher (2002), chef för engelska SCIE, beskriver hur han och hans medarbetare stötte på problem när de arbetade med en systematisk kunskapsöversikt inom äldreomsorgens område. RCT- studier visade sig vara sällsynta - på goda grunder menade Fisher. De är helt enkelt inte särskilt väl ägnade att generera kunskap som går att använda i praktiken. En av de allvarligaste bristerna med experimentella studier, menar Fisher, är att de inte alls omfattar brukarnas perspektiv. Fisher redovisar erfarenheter från hälsoinformationens område. RCT- studier har visat sig vara bäst lämpade när det gäller att studera insatser där patienten förväntas vara passiv. För utvärderingar av insatser som kräver aktivitet från patientens sida har processtudier visat sig vara mera lämpade.

Fisher menar att det krävs en mer "raffinerad metodik» för att kunna utveckla arbetet med systematiska kunskapsöversikter än den metaanalys som experimentella studier ger underlag för. Översikterna måste bygga på en metodik som gör det möjligt att redovisa den mångfald av kunskap om sociala metoder som finns redovisat i vetenskapliga studier. Framför allt måste de inkludera studier genomförda med en kvalitativ metodik. Rådet från SCIE lyder därför: "Börja med att skaffa er en överblick, börja med att göra en systematisk karta (systematic mapping). Det spar tid och pengar och ni undviker att hamna i ett läge där ni upptäcker att ni försökt besvara en fråga som inte går att besvara, eller ni upptäcker att ni måste svara utifrån ett otillförlitligt underlag“ (Fisher 2005, min övers.). Även EPPI-centre vid University of London arbetar enligt denna metod, av mig kallad Kartmodellen. (Oakely et al. 2005).

Arbetet börjar med samtal med uppdragsgivaren för att tydliggöra uppdraget. Exempel på frågeställningar som belyses är: Vad för slags kunskap efterfrågas? Är det enbart insatsen som skall belysas eller även förutsättningarna för att genomföra den? Vad skall kunskapsöversikten användas till? Vem skall använda den - beslutsfattarna, praktikerna, brukarna eller samtliga?

När uppdraget är tydliggjort slår man fast vilka frågor som skall besvaras. Exempel på praktikrelevanta frågor är: Vad har insatsen för effekt? För vem eller vilka kan den vara lämplig? Vilken kunskapsbas vilar den på? Vad finns för empiriskt stöd för denna metod? Vad finns för teoretiskt stöd, vilka teoretiska begrepp är centrala och vilken uppfattning om problemets uppkomst och karaktär utgör grunden för metoden? Vad kräver den i form av utbildning, hur omfattande är den, hur vanligt förekommande?

Forskarna drar sig sedan tillbaka och 
utformar en sökstrategi, genomför datasökningen och återkommer till uppdragsgivaren med en översiktskarta som i stora drag visar vad det finns för kunskap på området och vad den har för karaktär. Vid detta andra möte står urvalsfrågorna i fokus: Givet denna kunskap om den/ de insatser som ni vill veta något om, hur vill ni gå vidare? Vilka frågor skall vi välja, vilka frågor skall vi omformulera, vad skall vi gå på djupet med? I denna dialog är uppdragsgivaren garant för att kunskapsöversikten kommer att innehålla relevant kunskap, forskaren garanterar att den blir tillförlitlig. Det betyder att forskaren kan rekommendera att frågor omformuleras därför att kunskapsläget inte är sådant att de går att besvara, eller att helt nya frågor formuleras därför att det visar sig att det finns kunskap nog att besvara dem. Det kan också betyda att det visar sig att vissa delområden är så väl utforskade att det är möjligt att gå på djupet med dem. Efter denna kartläggning tas beslut om vilka frågeställningar och vilka typer av studier den systematiska kunskapsöversikten skall grundas på.

Varje forskningstradition har sina egna kvalitetskriterier. Kvalitetsbedömning, analys och sammanställning av data extraherad från studier med olika design, kräver omfattande metodkunskaper. För att tillämpa Kartmodellen krävs därför en arbetsgrupp med bred kompetens. Kartmodellen är krävande, men den erbjuder en möjlig framtida utveckling av metodiken för att sammanställa systematiska kunskapsöversikter och ger utrymme för att lösa en del av de problem som RCT-modellen för med sig.

\section{Mot ett evidensbaserat socialt arbete}

Sedan 1970-talet har det skapats en kritisk tradition för att studera det sociala arbetets praktik. Inom delar av den svenska samhällsvetenskapliga forskningen har det utvecklats ett sätt att betrakta socialt arbete som tagit som sin utgångspunkt $i$ att det är något inneboende fel med socialt arbete; att de insatser som görs per definition är förtryckande och otillräckliga och att det är forskarens uppgift att påvisa detta. Inom denna tradition riktas intresset såväl mot det sociala arbetets organisationsform, som dess arbetssätt och resultat.

Det evidensbaserade sociala arbetet (ESA) bryter med denna tradition och menar att forskarens uppgift är den motsatta, nämligen att identifiera den bästa praktiken och låta den utgöra basen för metodutveckling och lärande i socialt arbete. Jag tror att majoriteten av socialarbetare sympatiserar med denna ambition. Önskan att göra skillnad är något som förenar alla socialarbetare. Därför menar jag att ESA är ett intressant projekt, med potential att utveckla det sociala arbetets praktik.

En särskild uppgift inom ESA består av att göra systematiska kunskapsöversikter som bygger på primärstudier av sociala metoder. Dessa systematiska kunskapsöversikter utgör centrala dokument som inom ESA och är vägledande för hur det sociala arbetet bör utföras i praktiken och för hur det bör utvecklas. En förutsättning för att kunskapsöversikterna skall kunna fylla en sådan funktion är att de håller god vetenskaplig kvalitet. Kunskapsöversikter 
med låg grad av giltighet och tillförlitlighet kan leda till att socialarbetare mot bättre vetande utför ett dåligt socialt arbete eller så kommer de att leda till att projektet ESA marginaliseras.

I artikeln har jag starkt ifrågasatt RCTmodellens förmåga att leverera översikter av god vetenskaplig kvalitet. En viktig förutsättning för att kunskapsöversikterna skall fylla sin funktion som styrdokument i det sociala arbetet, är att de ställer praktikens kunskapsbehov i fokus. Den vägledande frågan för att avgöra om en översikt har praktikens kunskapsbehov i fokus och håller en god vetenskaplig kvalitet, bör enligt min mening formuleras på följande sätt: Är det för det sociala arbetet praktikrelevant data som samlats in och analyserats på ett vetenskapligt tillförlitligt sätt?

Det sociala arbetet karaktäriseras dock inte enbart av viljan att göra skillnad - en vilja som förvisso inte finns enbart hos socialarbetaren, utan $i$ än högre grad hos brukaren av det sociala arbetets insatser. Socialt arbete kan inte reduceras till sin intention, det karaktäriseras framför allt av den process och det samhandlande som äger rum mellan socialarbetare och brukare. Socialt arbete är ett socialt handlande som är beroende av sitt kulturella och sociala sammanhang. För att kunna vara relevant för praktiken kan de systematiska kunskapsöversikterna inte låta sig nöja med att besvara frågor om vilka metoder som är verksamma - de måste även kunna besvara frågor om var, när och hur de är verksamma, samt vilken mening de tillskrivs av socialarbetare och brukare.

Därför måste de systematiska kunskapsöversikterna även inkludera studier som bygger på en metod och design som gör det möjligt att besvara dessa frågor - det vill säga, metoder som etnografi, narrativ analys, konversationsanalys och grounded theory, för att nämna några exempel. Om inte de systematiska kunskapsöversikterna - och därmed EBA-projektet som helhet - endast skall få en marginell betydelse för socialt arbete, så måste definitionen av vad som är praktikrelevant data för det sociala arbetet omfatta även vad som brukar kallas kvalitativa studier. Även inom den evidensbaserade medicinen arbetar man med kvalitativa studier inom områden som rör exempelvis interaktionen mellan läkare och patient (se exempelvis Mishler 1984 och Charon 2006).

Min bedömning är att ESA är ett projekt med potential att utveckla det sociala arbetets praktik. Det har dock långt ifrån funnit sin form - det är i högsta grad ett utvecklingsprojekt. Det jag föreslår för den fortsatta utvecklingen är en mer ambitiös modell för framställning av systematiska kunskapsöversikter än den som Campbell Collaboration föreskriver, en utveckling som ligger mer i linje med det arbetssätt som tillämpas i England. Det främsta skälet till mitt förslag är att det sociala arbetet behöver svar på frågor om vad som är verksamt och vad som inte är det - men det behöver även veta på vilket sätt de är verksamma och vad de betyder för brukare och socialarbetare. Randomiserade kontrollerade studier och kvasiexperiment av hög kvalitet är betydelsefulla för att kunna besvara den första typen av frågor, medan det krävs studier som bygger på kvalitativa metoder av hög kvalitet, för att besvara den senare typen av frågor. De olika typerna av studier kvalitetsgranskas sedan på sina egna villkor. 
Ett ytterligare skäl till mitt förslag är att det skulle bidra till att minska det gigantiska bortfall av primärstudier som Campbell Collaborations modell leder till, något som avsevärt skulle kunna höja kvaliteten på översikterna. Arbetsprocessen bör därför lämpligen börja med en beskrivning av helheten av studier som finns inom det fält som kunskapsöversikten gäller, för att sedan gå vidare med arbetet att välja de studier som översikten skall grundas på.

De primärstudier som inkluderats i de systematiska översikter jag tagit upp i artikeln är amerikanska, i något fall brittiska. Det jag saknat i översikterna är en bedömning av metodernas relevans för svenskt socialt arbete, samt en gradering av hur användbara de kan vara i Sverige. Det betyder att en studie av hög kvalitet, men som beskriver en metod som rör förhållanden som befinner sig långt ifrån de svenska, kan komma att tillmätas en mindre betydelse än vad som är motiverat om man enbart skulle ta hänsyn till studiens kvalitet. Att bygga svenska kunskapsöversikter på studier av hög kvalitet men som beskriver metoder som har låg relevans för svenska förhållanden, innebär enligt min mening att kunskapsöversiktens kvalitet kan ifrågasättas eftersom den inte förmår att leva upp till de grundläggande krav på relevans som är rimligt att ställa på svenska systematiska kunskapsöversikter.

\section{Referenser}

Anttila S, Ericson C, Glad J, Fredriksson M, Olofsson H, Smedslund G, Klingspor K \& Hydén M (2006) Utfall och effekter av sociala metoder för kvinnor som utsatts för våld $i$ nära relationer. Stockholm: Socialstyrelsen/IMS.

Bergmark, A. \& Lundström, T. (2006) "Mot en evidensbaserad praktik? - Om färdriktningen i socialt arbete", Socialvetenskaplig tidskrift, 13 s. 99-113.

Bergmark, A. \& Lundström, T. (2007) »Kartan och terrängen - om en evidensbaserad praktik (EPB) som ideal och verklighet", Socialvetenskaplig tidskrift, 14 s. 77-82.

Charon, R. (2006) Narrative medicine: honoring the stories of illness. Oxford: Oxford University Press.

England, H. (1986) Social work as art: Making sense of good practice. London: Allen \& Unwin.
Fergusson, H. (2003) „Ouline of a Clinical Best Practice Perspective on Social Work and Social Care", British Journal of Social Work, 33 pp. 1005-1024.

Fisher, M. (2002) »The Social Care Institute for Excellence: The role of service users in problem formulation and technical aspects of social research", Social Work Education, 21 pp. 141-147.

Fisher, M. (2005) "Knowledge production in social welfare: enhancing the evidecebase». I P. Sommerfeld (ed.) Evidence-based social work. Towards a new professionalism? Bern: Peter Lang.

Gambrill, E. (1999)»Evidence-based practice: an alternative to authority-based practice. Families in Society", The Journal of Contemporary Human Services, 80 pp. 341-50. 
Gibbs, L. \& Gambrill, E. (2002) „Evidence based practice: Counterarguments to objections", Research on Social Work Practice, 12 pp. 452-476.

Gilgun, J. (2005) "The four cornerstones of evidence-based practice in social work", Research on Social Work Practice, 15 pp. 52-61.

Hydén, L-C. \& Hydén, M. (1997) Att studera berättelser. Samhällsvetenskapliga och medicinska perspektiv. Stockholm: Liber.

Konnerup, M. (2005) Evidence-based policy \& practice and systematic Campbell reviews - a vision and a tool. Föreläsning vid IMS konferens om ökad evidensbasering i socialtjänsten, Stockholm 10 oktober 2005. www.socialstyrelsen.se/ims.

Marthinsen, E. (2004) „Evidensbasert - praksis og ideologi", Nordiskt Socialt Arbeid, 24 s. 290-300.

McNeece, C.A. \& Thyer B.A. (2004) "EvidenceBased Pactice and Social Work", Journal of Evidence Based Social Work, 1 s. 7-25.

Mishler, E. (1984) The discourse of medicin: dialectics of medical interviews. Norwood, NJ: Ablex.

Månsson, S A. (2003) "Att förstå sociala insatsers värde", Nordiskt Socialt Arbeid, 23 s. 73-80.

Oakely A, Gough D, Oliver S \& Thomas J (2005) "The politics of evidence and methodology: lessons from EPPI-Centre», Evidence \& Policy, 1 pp. 5-31.

Sackett, D. et al. (1996) „Evidence-based medicin: what is it and what it isn't", British Journal of Medicin, 312 pp. 71-72.

Schön, D. A. (1991). The Reflective Practitioner. How Professionals Think in Action. Avebury:
The Academic Publishing Group.

Sheldon, B. (2001) "The validity of evidence-based practice in social work: A reply to Stephen Webb«, British Journal of Social Work, 31 pp. 801-11.

Sundell K, Hansson K, Andrée Löfholm C, Olsson T, Gustle L-H \& Kadesjö C (2006) Multisystemisk terapi för ungdomar med allvarliga beteendeproblem. Stockholm: Socialstyrelsen/IMS.

Regehr C, Stern S \& Shlonsky A (2007) "Operationalizing evidence-based pactice: The development of an institute for evidence-based social work", Research on Social Practice, 17 pp. 408-416.

Thyer, B. (2001) "What is the role of theory in research on social work practice?" Journal of Social Work Education, 37 pp. 9-25.

Webb, S. (2001) "Some considerations on the validity of evidence-based practice in social work", British Journal of Social Work, 31 pp. 57-79. www.campellcolloboration.org (november 2007) www.roks.se (november 2007) www.sisiaaliporti.fi/godpraktik (november 2007) www.skr.se (november 2007) www.socialstyrelsen.se/IMS (november 2007) www.socialstyrelsen.se/IMS/Campell_Colloboration (november 2007)

www.stakes.fi (november 2007)

Öjehagen, A. et al. (2006) Effekter av psykosociala insatser för personer med schizofreni eller bipolär sjukdom. En sammanställning av systematiska översikter. Stockholm: Socialstyrelsen/ IMS. 


\section{Summary}

\section{Evidence-based social work in Swedish-compiling systematic reviews of evidence}

The systematic review of primary studies which summarizie large bodies of evidence that an intervention really works, plays a fundamental role for the evidence-based social work practice. The review can be of great value to practitioners who feel overwhelmed by the volume of social work literature and, as a result, have to rely on limited information gathered in unsystematic ways. In order to be hepful to the practitioners, however, the systematic reviews in social work cannot be limited to answering the question "what works?" for one group of clients compared to another group of clients who did not get the intervention. The reviews must include answers to questions about "where, when and how " the interventions work, and what meaning social workers and clients attribute to them.

Recommendations are made in the article for the systematic reviews in social work not to exclusively favour primary studies designed as randomized controlled trials, but to open up for studies that use methods such as ethnography, narrative analysis, conversational analysis and grounded theory. These kinds of studies are more suited for the production of systematic reviews of fundamental importance for social work than RCT-studies, or studies based solely on quasi experiments. 